\title{
Quality control of pork used in the recipe for kebabs in a technogenic zone
}

\author{
Atsamaz Biboyev ${ }^{1, *}$, Rustem Temirayev ${ }^{1}$, Lada Vitiuk $^{1}$, Rita Zhylova $^{2}$, and Larisa \\ Shiritova ${ }^{2}$ \\ ${ }^{1}$ North Caucasus Mining Metallurgical Institute (State University of Technology), Nikolaeva 44, \\ 362021 Vladikavkaz, Russia \\ ${ }^{2}$ Kabardino-Balkarian State Agricultural University named after V.M. Kokov, Lenin Avenue, 1V, \\ 360030 Nalchik, Russia
}

\begin{abstract}
The investigation purpose was to conduct a comparative control for the consumer qualities of the store pigs meat of the Landrace Danish breeding (LDB) and their cross-breeds of different pedigree on a large white breed (LWB) according to the scheme: control - well-bred Landrace (LDB) animals: 1-st check - 1/2 LDB 1/2 LWB yelts; 2-nd check - 3/4 LDB 1/4 LWB animals and 3-rd check - 7/8 LDB 1/8 LWB yelts, as well as dish samples No. 278 "Pork kebab", for which the animals meat of the specified pedigree was used in the recipe. The "pork kebab" dish samples from the pork loin of the 3-rd check group distinguished by the best chemical composition. The dish sample of the 3-rd generation pork meat $(7 / 8$ LDB $\times 1 / 8$ LWB $)$ distinguished by the best ecology nutritious features, so that the 3-rd check sample contained lower level of zinc, lead and cadmium. By the total score of the 3-rd check sample of this 3-rd generation Landrace pork dish surpassed the control sample.
\end{abstract}

\section{Introduction}

For cooking kebabs, meat from pigs of different breed types is used: meat, bacon, combined (porky) breeds, but to ensure high consumer properties of kebabs, first of all, the ratio of protein and fat in pork should be taken into account. In this respect, it is preferable to use the purely meat breed pigs with the more optimal ratio because of a lower proportion of fat, but protein is more $[1,2,3,4]$.

In the North Caucasus, including in North Ossetia - Alania, the most common breed of pigs is the large white breed (LWB), which belongs to the combined breeds. Animals of this breed are very well adapted to local conditions, including ecology. Due to the increased emission of high-density metals into the environment, the Republic of North Ossetia Alania is one of the most polluted territories in the Russian Federation due to the large list of non-ferrous metallurgy enterprises in the city of Vladikavkaz, such as JSC "Electrozinc", JSC "Pobedit", etc. Recently, however, producers have begun to import high-yielding meat breeds, among which the animals of Landrace Danish breeding (LDB) distinguish for their excellent slaughter and meat qualities. But they are less adapted to local environmental

\footnotetext{
${ }^{*}$ Corresponding author: kapmar17@gmail.com
} 
conditions that causes a decrease in their meat productivity and the quality of pork $[5,6,7$, 8].

Taking this into account, in order to increase the adaptive qualities, meat productivity and consumer qualities of pork produced in the technogenic zone of the Republic of North Ossetia - Alania, introductory mating of Landrace Danish breeding sows (LDB) with breeding boars producing large white breeds (LWB) is carried out, and subsequently, crossbreeds of the 1-st and 2-nd generations are mated with Landrace breeding boars $[9,10$, $11,12]$.

The investigation purpose was to conduct a comparative control for the consumer qualities of the store pigs meat of the Landrace Danish breeding (LDB) and their crossbreeds of different pedigree on a large white breed (LWB) according to the scheme: control - well-bred Landrace (LDB) animals: 1-st check - 1/2 LDB 1/2 LWB yelts; 2-nd check 3/4 LDB 1/4 LWB animals and 3-rd check - 7/8 LDB 1/8 LWB yelts, fattened in the technogenic zone of RNO -Alania, as well as dish samples No. 278 "Pork kebab", for which the animals meat of the specified pedigree was used in the recipe.

\section{Materials and methods}

In the course of our investigations, the subjects of investigations were:

- when obtaining meat for processing - different pedigree hog carcasses on large white breeding (LWB) and Landrace Danish breeding (LDB), killed at the age of 7.5 months;

- dish samples, cooked according to the recipe No.278 "Pork kebab", from the pork loin of different pedigree.

To obtain different pedigree hog carcasses for large white breeding (LWB) and Landrace Danish breeding (LDB), we fed store pigs for meat production of different pedigree on large white breeding (combined or porky type), selected at the age of 2 months. At the same time, the introductory mating of Landrace Danish breeding sows (LDB) with breeding boars producing large white breeds (LWB) was carried out, and subsequently, crossbreeds of the 1-st and 2-nd generations were mated with Landrace breeding boars.

In accordance with the investigation scheme in the course of fattening store pigs at the age of two months formed, on the principle of analogue pairs (taking into account gender, age, breed, origin and live mass) 4 yelt groups of 15 heads each:

- control - well-bred Landrace (LDB) animals:

- 1-st check - 1/2 LDB x 1/2 LWB yelts;

- 2-nd check - 3/4 LDB x 1/4 LWB animals

- 3-rd check - 7/8 LDB x 1/8 LWB yelts.

\section{Investigation results and discussion}

In order to obtain different pedigree hog carcasses for large white breed (LWB) and Landrace Danish breeding (LDB) under the conditions of the Republic of North Ossetia Alanya we fed Landrace store pigs for meat production of different pedigree on large white breeding. The slaughter indexes are shown in Figure 1 and the linear parameters of hog carcasses are shown in Figure 2. 


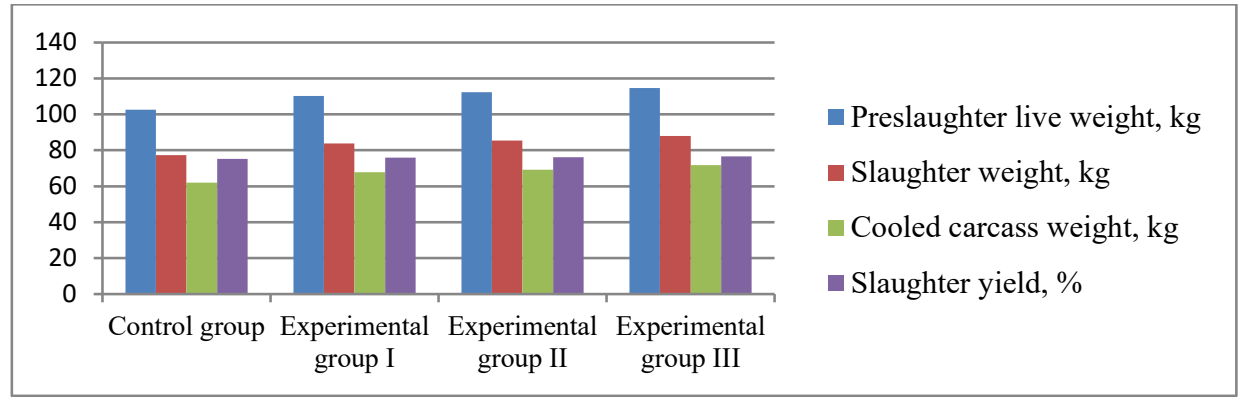

Fig. 1. Animal slaughter indexes of comparable groups.

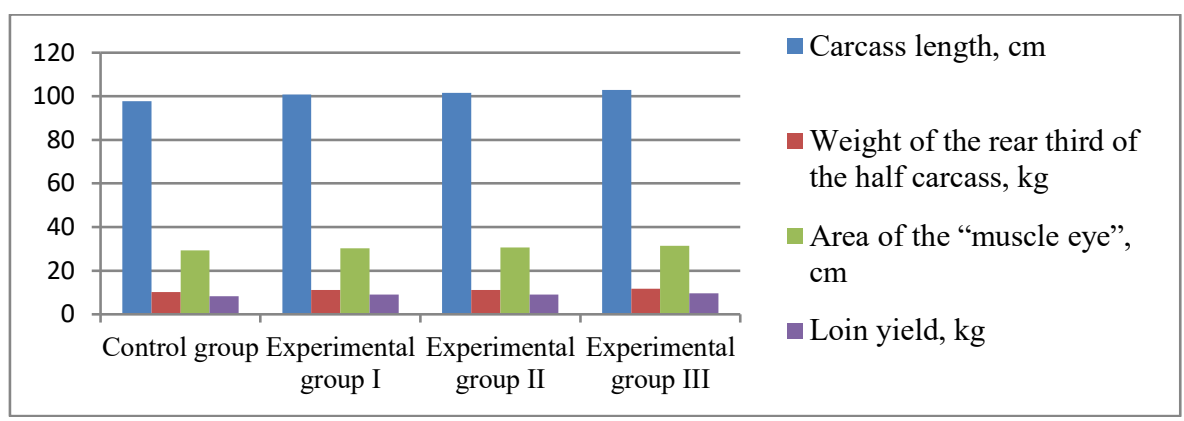

Fig. 2. Linear indexes of yelt carcasses.

Compared with the control group, there are significantly $(\mathrm{P}<0.05)$ better indexes of preslaughter live weight by $12.02 \mathrm{~kg}$, slaughter weight - by $10.74 \mathrm{~kg}$, slaughter yield - by $1.48 \%$, chilled carcass weight - by $9.70 \mathrm{~kg}$, the carcass yield - by $2.14 \%$ and the weight of the rear third of the half carcass - by $1.01 \mathrm{~kg}$, the area of the "muscle eye" - 1 by $2.09 \mathrm{~cm}^{2}$ and the loin yield - by $1.46 \mathrm{~kg}$ were yelts of the $3 \mathrm{rd}$ check group.

The chemical composition (Figure 3), the biological value of protein (Figure 4) and the availability of heavy elements (Figure 5) in samples of the animals longest muscle of the back are studied in the traditional way.

The best indexes of chemical composition and biological fullness were the yelt meat of the 3 check group, reliably $(\mathrm{P}<0.05)$ surpassing control on the content of dry matter by $0.72 \%$, protein - by $0.8 \%$, the size of protein quality index (PQI) - by $6.6 \%$. Compared to the animals meat of the control group, the meat sample of the yelts of the 3 -rd check group was inferior in terms of energy value by $2.03 \mathrm{kcal} / 100 \mathrm{~g}$

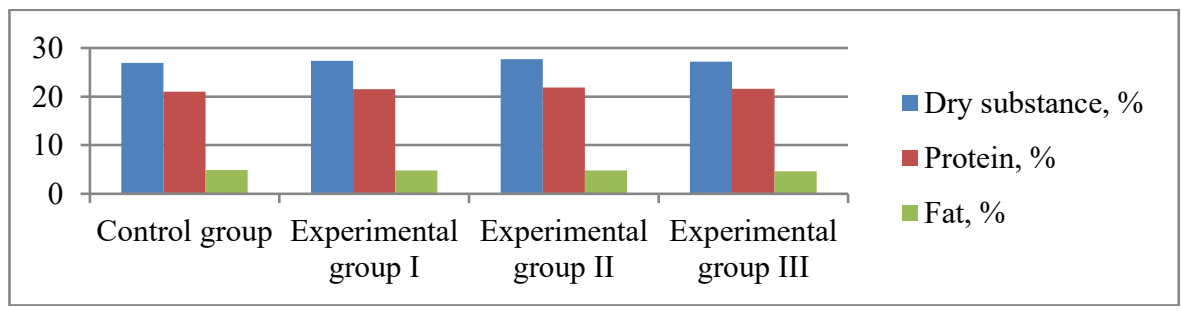

Fig. 3. The chemical composition of pork meat. 


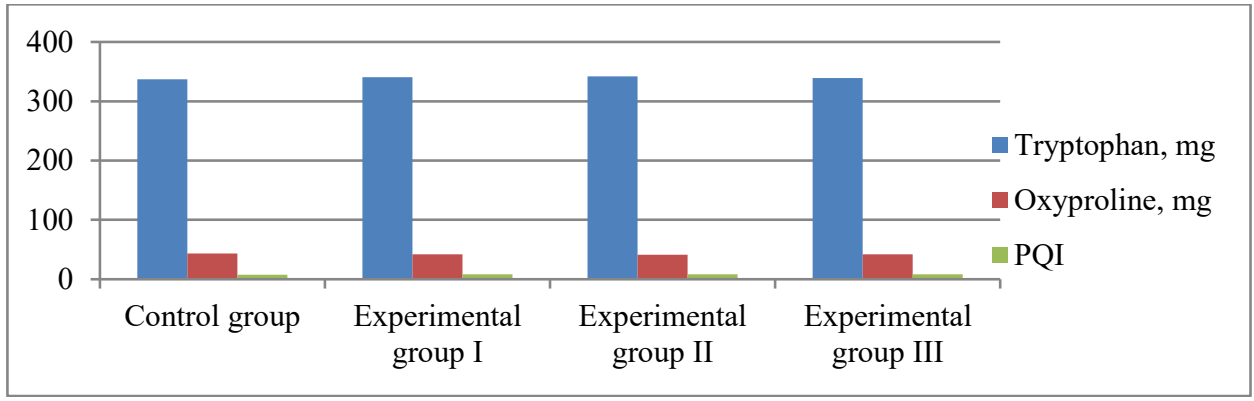

Fig. 4. The biological value of the yelt meat.

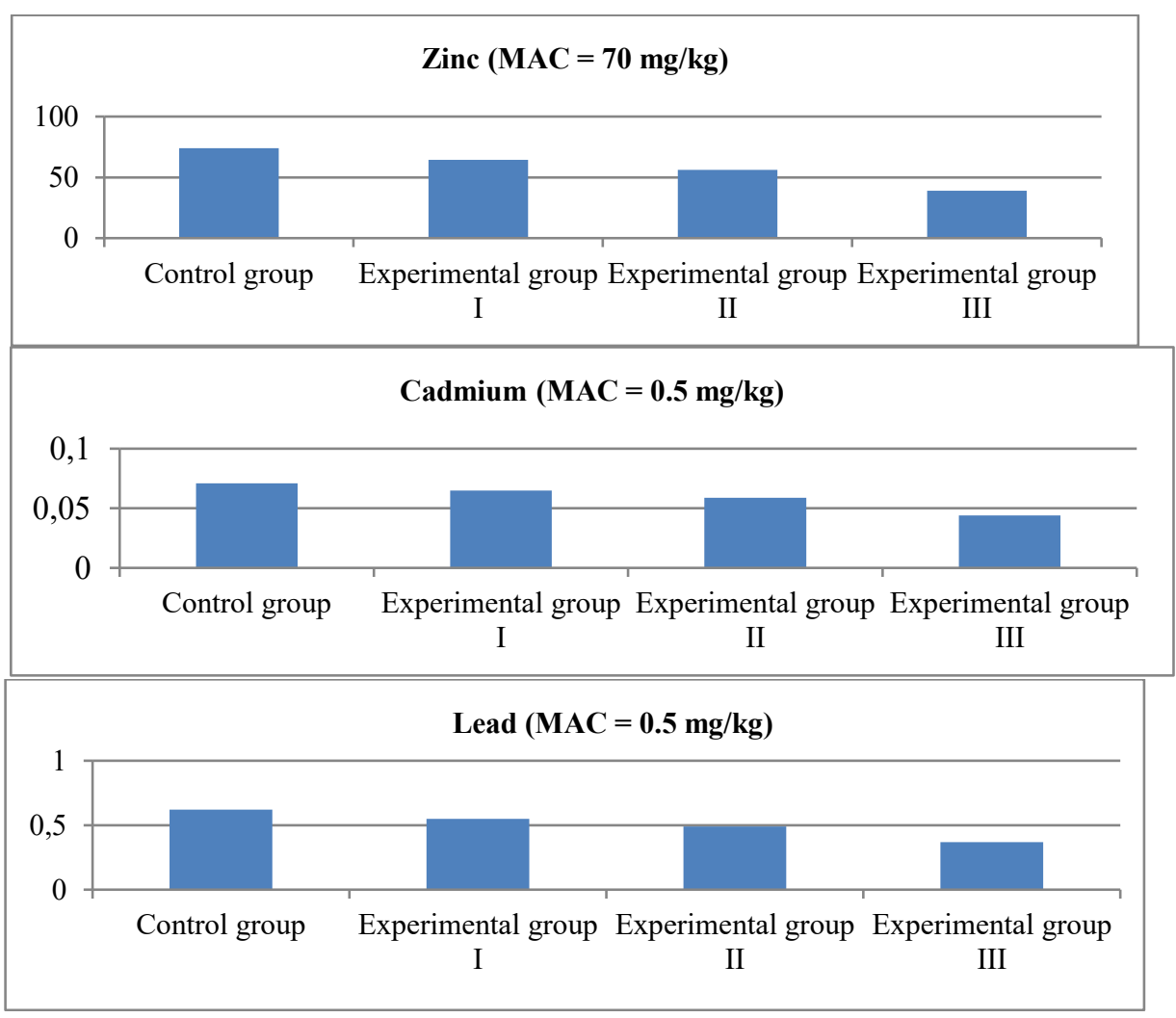

Fig. 5. Concentration of high-density metals in the meat of yelts.

The animals in the 3-year-old group (7/8 LDB x 1/8 LWB) had a reliably lower concentration of zinc by 1.90 times, lead by 1.68 and cadmium by 1.61 times, respectively. Moreover, the store pigs of the 3-rd check group have the concentration that did not exceed the maximum allowable concentrations (MAC) in any case.

In the compared samples of loin from the yelt carcasses of the compared groups studied indexes of water-holding capacity, diameter of muscle fiber (Figure 6) and $\mathrm{pH}$ of meat, determined immediately after slaughter, as well as after 24 hours of soaking.

According to the data obtained, the highest level of water-holding capacity, muscle fiber diameter was characteristic of the store pigs meat of the 3 rd check group (7/8 LDB x 1/8 LWB), reliably $(\mathrm{P}<0.05)$ surpassing the control analogues in these indexes by $7.97 \%$ and $5.10 \mu \mathrm{m}$ [55]. 
The animal meat $\mathrm{pH}$ value of the compared group immediately after slaughter, as well as after 24 hours of soaking, was within the normal range.

The following process chart and cooking scheme for dish No. 278 "Pork kebab" from the meat of animals of the compared groups (Table 1) is given below.

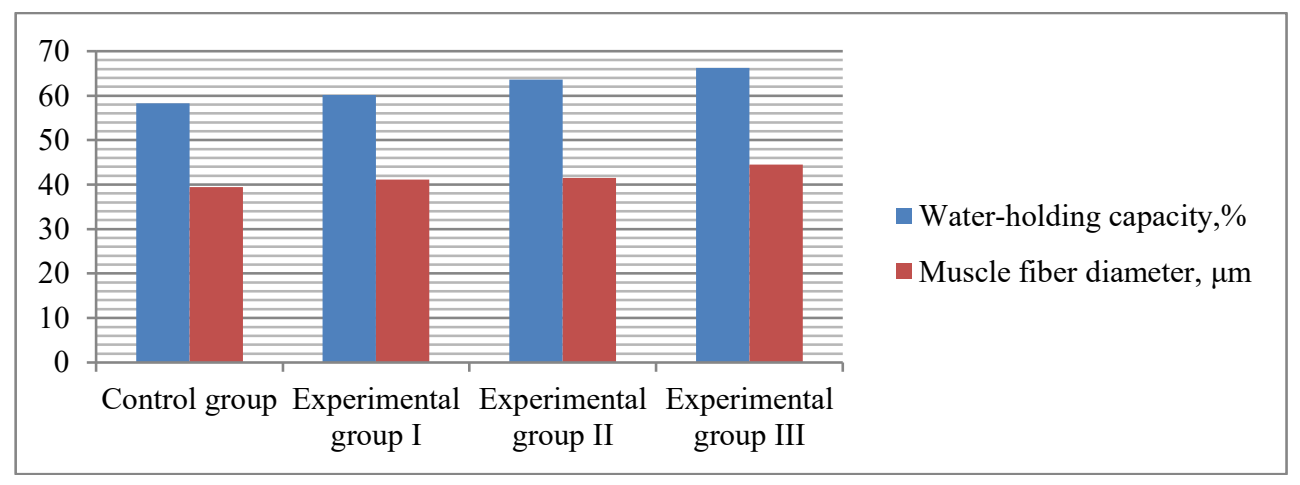

Fig. 6. Some physical indexes of yelt meat.

Table 1. Process chart Dish name: No. 278 "Pork kebab".

\begin{tabular}{|c|c|c|c|c|c|}
\hline & \multirow[t]{2}{*}{ Product name } & \multicolumn{2}{|c|}{$\begin{array}{l}\text { Weight of products } \\
\text { per } 1 \text { portion, } g\end{array}$} & \multicolumn{2}{|c|}{$\begin{array}{l}\text { Weight of products per } 10 \\
\text { portions, } \mathrm{g}\end{array}$} \\
\hline & & Gross weight & Net weight & Gross weight & Net weight \\
\hline 1 & Pork (loin) & 177 & 127 & 1770 & 1270 \\
\hline 2 & Onion & 26 & 21 & 260 & 210 \\
\hline 3 & Salt & 4 & 4 & 40 & 40 \\
\hline 4 & Ground black pepper & 4 & 4 & 40 & 40 \\
\hline 5 & Ground red pepper & 4 & 4 & 40 & 40 \\
\hline 6 & Dried dill (khionthora) & 4 & 4 & 40 & 40 \\
\hline 7 & Bay leaf & 0.03 & 0.03 & 0.3 & 0.3 \\
\hline \multirow[t]{2}{*}{8} & Mineral water & - & - & 1500 & 1500 \\
\hline & Fried kebab weight & - & 85 & - & 850 \\
\hline \multicolumn{6}{|c|}{ Side dish: } \\
\hline 9 & Fresh tomatoes & 126 & 107 & 1260 & 1070 \\
\hline 10 & Fresh cucumbers & 120 & 100 & 1200 & 1000 \\
\hline 11 & Green onion & 27 & 22 & 270 & 220 \\
\hline 12 & Onion & 26 & 22 & 260 & 220 \\
\hline 13 & Salt & 4 & 4 & 40 & 40 \\
\hline \multicolumn{6}{|c|}{ Spicy tomato sauce: } \\
\hline 14 & Coriander & 40 & 40 & 400 & 400 \\
\hline 15 & Spicy pepper & 20 & 18 & 200 & 180 \\
\hline 16 & Onion & 30 & 26 & 300 & 260 \\
\hline 17 & Ground black pepper & 6 & 6 & 60 & 60 \\
\hline 18 & Tomato Paste & 55 & 55 & - & - \\
\hline \multirow[t]{2}{*}{19} & Water & $10-20$ & $10-20$ & - & - \\
\hline & Yield of & - & 250 & - & 2500 \\
\hline
\end{tabular}

Meat, cut into 30-40 g cubes (3-4 pieces per portion), sprinkle with salt, pepper (black and red), dried dill, add raw chopped onions (lightly poured with vinegar), bay leaf and mineral water, mix, and put in cold place for 2-6 hours.

The marinated meat is put on a skewer and fried over hot coals or on the grill.

Sprinkle pickled onions (vinegar, pepper, salt) on the finished kebab and leave for a few minutes.

Garnish (fresh vegetable salad). Chop tomatoes, cucumbers, onions and green onions. Then add salt and pepper to taste, then mix. 
Preparation of the sauce. Finely chop the onion (turnip-shaped), fresh pepper (spicy), coriander. Dilute the tomato with water and add the previously chopped onion, coriander and pepper. Then add pepper and salt to taste and mix well.

The meat shall be roasted on both sides and brown in color. The consistency of the meat cut is tender, the color is red-brown. The smell is specific, peculiar for marinated meat.

The chemical composition and nutritional value (Fig. 7) and the concentration of highdensity metals (Fig. 8) of the "Pork kebab" compared samples are given below.

The best chemical composition was observed in the samples of the prepared dish from the pork loin of the 3-rd check group, which relative to the control sample was appeared in an increase in protein content by $0.87 \%(\mathrm{P}<0.05)$ and a decrease in fat concentration by $0.84 \%$ and energy value by $3.02 \mathrm{kcal} / 100 \mathrm{~g}$.

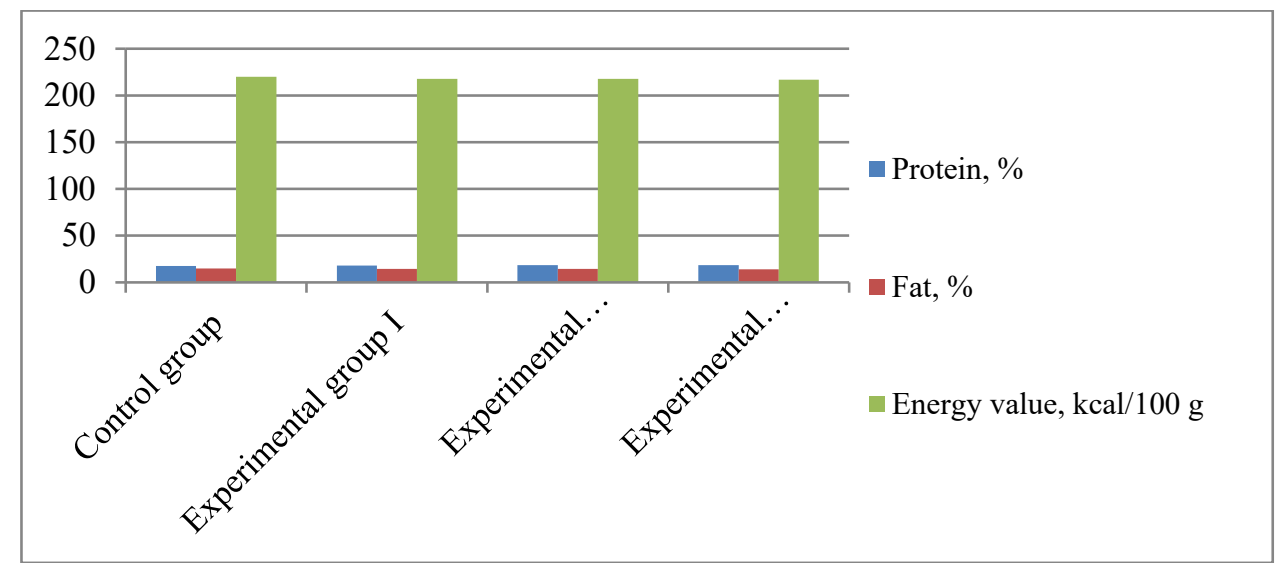

Fig. 7. Chemical composition of "Pork kebab" dish samples.

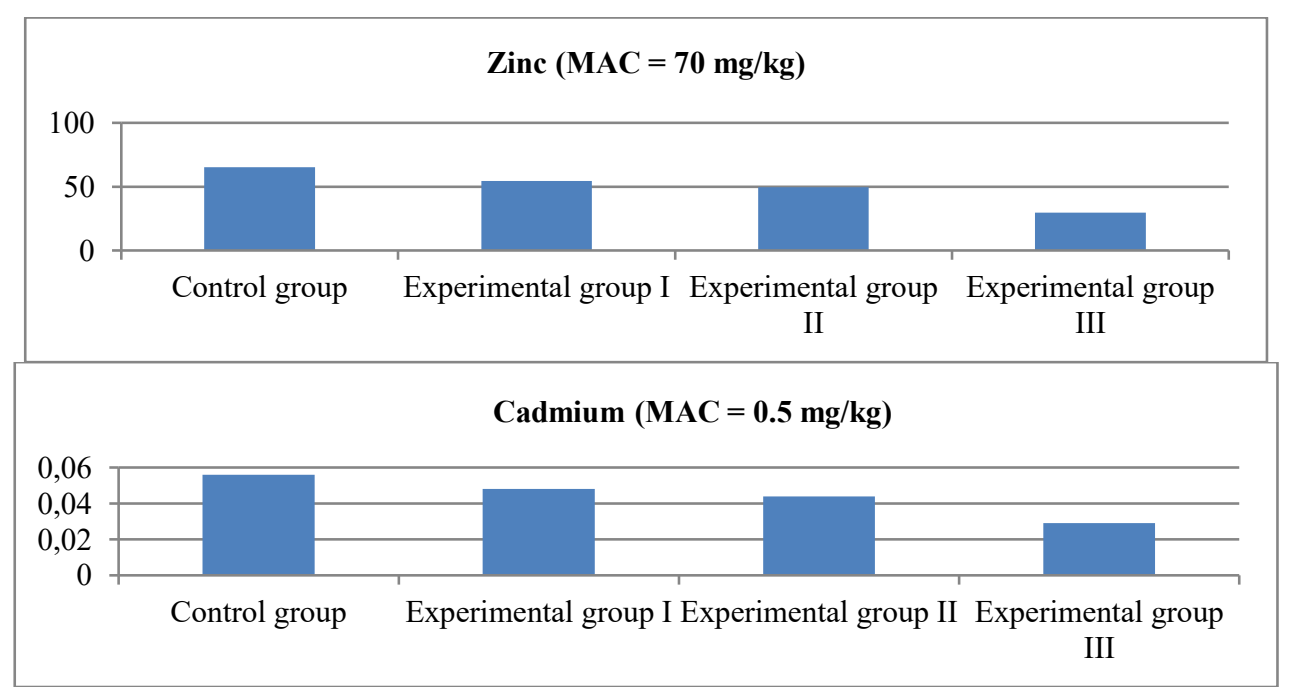




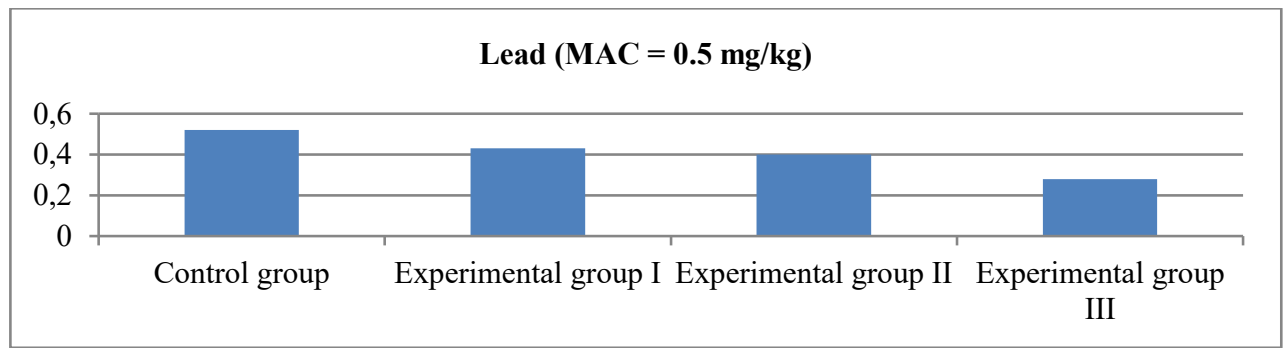

Fig. 8. Concentration of high-density metals in the "Pork kebab" dish samples.

The best ecological nutritional properties were distinguished by the No. 278 "Pork kebab" dish sample from the pork meat of the 3-rd generation, in which, relative to the control, there was a significant $(\mathrm{P}<0.05)$ lower content of zinc by 2.19 times, lead - by 1.86 and cadmium - 1.93 times. In the compared samples of the ready-made product, the content of high-density metals was lower than the MAC, with the exception of the availability of lead and cadmium in the control sample.

The taste panel consisting of 7 people carried out an organoleptic assessment of No. 278 "Pork kebab" dish samples (Table 2) according to the five-point scale.

Table 2. "Organoleptic assessment of No. 278 "Pork kebab" dish samples.

\begin{tabular}{|c|c|c|c|c|}
\hline \multirow{2}{*}{ Indicator } & \multicolumn{4}{|c|}{ sample } \\
\hline & control & 1 test & 2 test & 3 test \\
\hline Appearance & $4.73 \pm 0.04$ & $4.83 \pm 0.05$ & $4.86 \pm 0.05$ & $4.89 \pm 0.02$ \\
\hline Sectional color & $4.67 \pm 0.04$ & $4.70 \pm 0.05$ & $4.71 \pm 0.05$ & $4.87 \pm 0.05$ \\
\hline Taste & $4.71 \pm 0.04$ & $4.77 \pm 0.05$ & $4.82 \pm 0.05$ & $4.90 \pm 0.04$ \\
\hline Aroma & $4.86 \pm 0.06$ & $4.88 \pm 0.03$ & $4.90 \pm 0.04$ & $4.94 \pm 0.02$ \\
\hline Juiciness & $4.87 \pm 0.05$ & $4.90 \pm 0.04$ & $4.88 \pm 0.07$ & $4.89 \pm 0.04$ \\
\hline Tenderness & $4.80 \pm 0.03$ & $4.82 \pm 0.03$ & $4.82 \pm 0.04$ & $4.84 \pm 0.03$ \\
\hline Overall grade & $28.64 \pm 0.05$ & $28.90 \pm 0.04$ & $28.99 \pm 0.06$ & $29.33 \pm 0.04$ \\
\hline
\end{tabular}

Statistical processing of the results for the organoleptic assessment of the compared samples showed that, according to the overall grades the 3-rd check sample of No. 278 "Pork kebab" dish from pork meat of the 3 -rd generation $(7 / 8 \mathrm{LDB} \times 1 / 8 \mathrm{LWB})$ for the Landrace breed is reliable $(\mathrm{P}<0.05)$ surpassed the control sample from well-bred Landrace pigs by 0.69 grade, primarily due to the assessments in taste, sectional color, appearance and aroma.

Consequently, under the conditions of the technogenic zone of North Ossetia - Alania, the best physicochemical properties and environmental safety are distinguished by the meat of the third generation Landrace Danish breeding for large white breed (7/8 LDS $\times 1 / 8$ KBP), whose adaptive mechanisms are better developed, ensuring the level of accumulation of high-density metals in muscle tissue. This contributed to an increase in the nutritional value, sanitary and hygienic properties of meat and the organoleptic properties of the "Pork kebab" dish (recipe No. 278 of the Collection of recipes for dishes and culinary products for public catering enterprises).

\section{Conclusions}

1. It was found that with an excessive background of high-density metals in comparison with well-bred yelts of the Landrace Danish breeding for meat productivity (LDB), animals of the 3-rd generation (7/8 LDB x 1/8 LWB) have the best slaughter indexes for large white breed (LWB). 
2. The results of the chemical analysis for the longest muscle of the back showed that, against the control sample, in the meat of animals of the 3-rd check group of calves $(7 / 8$ LDB $1 / 8$ LWB), there was a significantly $(\mathrm{P}<0.05)$ higher dry matter content by $0.72 \%$, protein - by $0.8 \%$, the value of the protein-quality index (PQI) - by $6.6 \%$, water-holding capacity by $7.97 \%$ and muscle fiber diameter - by 5.10 microns with a decrease in the level of zinc content by 1.90 times, lead - 1.68 times and cadmium - 1.61 times, respectively.

3. The No. 278 "Pork kebab" dish samples prepared from the pork loin of the 3-rd check group, $(7 / 8 \mathrm{LDB} \times 1 / 8 \mathrm{LWB})$ distinguished by the best chemical composition, which relative to the control sample was appeared in an increase in protein content by $0.87 \%$ $(\mathrm{P}<0.05)$ and a decrease in fat concentration by $0.84 \%$ and energy value by $3.02 \mathrm{kcal} / 100 \mathrm{~g}$.

4. The best ecological nutritional properties were distinguished by the No. 278 "Pork kebab" dish sample from the pork meat of the 3 -rd generation $(7 / 8 \mathrm{LDB} \times 1 / 8 \mathrm{LWB})$, thanks to it in the 3-rd check sample, relative to the control, there was a significant $(\mathrm{P}<0.05)$ lower content of zinc by 2.19 times, lead - by 1.86 and cadmium - 1.93 times. In addition, in the compared samples of the ready-made product, the content of high-density metals was lower than the MAC.

5. According to the overall grades the 3-rd check sample of No. 278 "Pork kebab" dish from pork meat of the 3 -rd generation $(7 / 8 \mathrm{LDB} \times 1 / 8 \mathrm{LWB})$ for the Landrace breed surpassed the control sample from well-bred Landrace pigs by 0.69 grade, primarily due to the assessments in taste, sectional color, appearance and aroma.

\section{References}

1. V. K Temiraev, V. R. Kairov, R. V. Kalagova, Biology and Medicine, 6, 3, (2014)

2. V. A. Pogodaev, A. N. Arilov, A. F. Shevhuzhev, A. P. Marynich, R. H. Kochkarov, Research Journal of Pharmaceutical, Biological and Chemical Sciences, 8(1),10861090 (2017)

3. V. V. Tedtova, Z. T. Baeva, E. S. Dzodzieva, Z. Ya. Tsopanova, A. H. Pilov, Meat Industry, 3, 60-62 (2013)

4. Y. A., Yuldashbaev, R. V. Temiraev, V. V. Tedtova, K. V. Temiraev, R. V. Osikina, M. S. Gazzaeva, L. H., Shugusheva, I. K Sattsaeva, M. M. Udychak, Journal of Livestock Science, 11, 8-13 (2020)

5. S. F. Sukhanova, S. I. Kononenko, R. V. Temiraev, T. T. Tarchokov, Z. T. Baeva, L. A. Bobyleva, B. M. Shipshev, Journal of Pharmaceutical Sciences and Research, 10, 11, 2969-2971(2018)

6. S. F. Sukhanova, S. I. Kononenko, R. V. Temiraev, T. T. Tarchokov, Z. T. Baeva, L. A. Bobyleva, B. M. Shipshev, Journal of Pharmaceutical Sciences and Research, 10(11), 2969-2971(2018)

7. V. K Temiraev, V. R. Kairov, R. V. Temirayev, Z. A. Kubatieva and V. M. Gukezhev, Ecology, Environment and Conservation, 23(1), 554-561 (2017)

8. R. B. Temirayev, L. V. Tsaliyeva, I. G. Pliyeva, M. R. Dzutseva, The Gorsky State Agricultural University news, , 47(2), 85-87 (2010)

9. L. V. Tsaliyeva, R. B. Temirayev, F. R. Balikoyeva, N. A. Pyshmantseva, Meat Industry, 11, 36-38 (2011)

10. R. Temirayev, V. Kairov, E. Khamitsayeva, T. Tuayeva, V. Gasiyeva, Compound feed, 4, 70 (2008)

11. A. A. Sokolov, Food Industry (2011) 
12. O. N. Krasulia, A. V. Smirnova, V. I. Bogush, Ye. A. Yushina, Meat Industry, 5, 45-48 (2020) 